\title{
Assessment of $\mathrm{NH}_{3}$ Reduction and $\mathrm{N}_{2} \mathrm{O}$ Production during Treatment of Exhausted Air from Fattening Pigs Building by a Commercial Scrubber
}

\author{
Laurence Loyon ${ }^{1,2}$, Philippe Dupard1,2, Patricia Saint-Cast ${ }^{1,2}$, Fabrice Guiziou1,2 \\ ${ }^{1}$ Irstea, UR OPAALE, Rennes, France \\ ${ }^{2}$ Université Européenne de Bretagne, Rennes, France \\ Email: laurence.loyon@irstea.fr
}

How to cite this paper: Loyon, L., Dupard, P., Saint-Cast, P. and Guiziou, F. (2016) Assessment of $\mathrm{NH}_{3}$ Reduction and $\mathrm{N}_{2} \mathrm{O}$ Production during Treatment of Exhausted Air from Fattening Pigs Building by a Commercial Scrubber. Agricultural Sciences, 7, 693-709.

http://dx.doi.org/10.4236/as.2016.710065

Received: August 25, 2016

Accepted: October 23, 2016

Published: October 26, 2016

Copyright $\odot 2016$ by authors and Scientific Research Publishing Inc. This work is licensed under the Creative Commons Attribution International License (CC BY 4.0).

http://creativecommons.org/licenses/by/4.0/

\section{(c) (i) Open Access}

\begin{abstract}
The use of air scrubbers to reduce ammonia $\left(\mathrm{NH}_{3}\right)$ emissions from buildings on pig farms is one of the most promising techniques in the Göteborg protocol and other European regulations including the Industrial Emission Directive. In France, some air scrubbers are currently used on pig farms, mainly to reduce odours from livestock buildings. However, recent research revealed the production of $\mathrm{N}_{2} \mathrm{O}$ resulting from the treatment of air from pig buildings. In this context, a two-month study was conducted on a pig farm with 750 places for fattening pigs to check the abatement of $\mathrm{NH}_{3}$ emissions and to assess the possible production of $\mathrm{N}_{2} \mathrm{O}$ during treatment of exhausted air from buildings housing fattening pigs by a air scrubber. Concentrations of $\mathrm{NH}_{3}$ and $\mathrm{N}_{2} \mathrm{O}$ in the inlet and outlet air of the scrubber were continuously monitored using an Innova 1412 infrared analyzer. With the scrubber operating parameters (airflow, design, size), our results confirmed the production of $\mathrm{N}_{2} \mathrm{O}$ in the order of $5 \%$ of $\mathrm{NH}_{3}-\mathrm{N}$ reduced. $\mathrm{N}_{2} \mathrm{O}$ was produced by biological nitrification and/or denitrification inside the air scrubber. Statistical analysis (Pearson's test) showed that the production of $\mathrm{N}_{2} \mathrm{O}$ was strongly influenced by the rate of airflow and the outside temperature. The abatement of $\mathrm{NH}_{3}$ emissions from the building was only $33 \%$, i.e. much lower than the $70 \%-90 \%$ usually cited in the literature.
\end{abstract}

\section{Keywords}

Wet Scrubber, Ammonia, Nitrous Oxide, Piggery, Air Treatment

\section{Introduction}

Livestock production is one of the human activities that has a negative impact on the 
environment through the emission of ammonia $\left(\mathrm{NH}_{3}\right)$ and greenhouse gases (GHG), especially methane $\left(\mathrm{CH}_{4}\right)$ and nitrous oxide $\left(\mathrm{N}_{2} \mathrm{O}\right)$ from livestock housing and manure management [1]-[4]. Among other livestock activities, pig housing is a serious source of $\mathrm{NH}_{3}$ [5].

France has to respect a series of international protocols, European directives and national regulations aimed at reducing the environmental impacts of livestock farming. Limitation of ammonia emissions is part of the Gothenburg Protocol (United Nations Convention on Long-range Transboundary Air Pollution-CLRTP [6] and the EU National Emissions Ceilings Directive [7]. The Kyoto Protocol under the United Nations Framework Convention on Climate Change-UNFCCC [8] targets the emissions of methane and nitrous oxide. An even stricter approach to implementing abatement measures had emerged from the Integrated Pollution Prevention and Control Directive (IPPC) 96/61/EC [9], which was recently incorporated in the Industrial Emissions Directive (IED) 2010/75/EU [10].

According to this legislative framework, ammonia limitation can be achieved by several available abatement options that are described in official documents: 1) "Guidance document for preventing and abating ammonia emissions from agricultural sources" [11] under the Gothenburg Protocol and 2) "Reference Document on Best Available Techniques for The Intensive Rearing of Poultry and Pigs" or BREF [12] emerging from the IED directive.

One of the main techniques used to reduce ammonia emissions from pig housing is to treat the exhaust air with an air scrubber. The principle of this technique, described in more detail elsewhere [13] [14], consists of passing the exhaust air from livestock buildings through a trickling bed filter which retains certain pollutants, including ammonia, as well as dust and odours [14] [15].

Different types of air scrubber are recommended for the removal of ammonia from exhaust air of piggery buildings. Most are classified in three types [16] [17]: wet scrubbers (also referred to water-only scrubbers or biotrickling filters), chemical scrubbers (acid for example) and air scrubber filters. Under certain conditions, a wet scrubber could have the same function as a biotrickling filter when a bacterial population develops on the inorganic packing material due to the accumulation of dust contained in the exhaust air from pig buildings [16] [17]. The use of an air scrubber is expected to reduce $\mathrm{NH}_{3}$ emissions from buildings by at least 70\% [11] [12] [14]. However, some recent studies showed that at the farm level, the actual reduction in $\mathrm{NH}_{3}$ by a biotrickling filter could in fact be less than $50 \%$ and, furthermore, that $\mathrm{N}_{2} \mathrm{O}$ is also produced [17] [18]. Indeed, the efficiency of an air scrubber depends to a great extent on the characteristics of the equipment (design, maintenance, renewal of the washing water, etc.) and on the operating conditions (ammonia loading rate, air ventilation, etc.) [17] [19] [20]. $\mathrm{N}_{2} \mathrm{O}$ is generally a by-product of nitrification/denitrification processes [21]. The production of $\mathrm{N}_{2} \mathrm{O}$ also depends on different parameters linked to the air scrubber including the ammonia loading rate, air humidity, temperature, and the composition of the washing water [20]-[22]. In a comparison of different studies, Van der Heyden et al. 
[20] reported that an increase in the residence time of the air in the scrubber appeared to increase the production of $\mathrm{N}_{2} \mathrm{O}$.

Air scrubbers are currently mainly used in French pig farms to reduce odours from livestock buildings to avoid possible conflicts with neighbors [23]. A recent French survey has estimated that air scrubbers are installed in about $5 \%$ of pig farm buildings [24]. According to the operating parameters of commercial scrubbers (airflow, design, size, etc.) the ammonia removal rate is lower than that targeted [19] [23].

In this context, a two-month study was conducted on a pig farm with 750 fattening pigs to assess the reduction in $\mathrm{NH}_{3}$ emissions and the possible production of $\mathrm{N}_{2} \mathrm{O}$ by a commercial air scrubber that had been installed to reduce efficiently odours from the pig building.

\section{Material and Methods}

\subsection{Pig Housing}

The study was carried out from September to November 2012 on a pig farm in Brittany (France). The air scrubber is installed to treat the air of a total of 750 fattening pigs in seven sections of one building. The floor of each section is slatted with a manure storage space underneath for the fattening period. Each room is mechanically ventilated by two fans with variable speed regulation to keep a constant inside temperature of around $26^{\circ} \mathrm{C}$. All the outlet air from all seven sections is combined in a depressurized air corridor and directed towards the inlet of the air scrubber by two large fans.

\subsection{Air Scrubber}

The commercial air scrubber at the pig farm surveyed had been installed outside the building to reduce obnoxious odours. This air scrubber seems to meet the needs because, according to the farmer, no complaints of local residents have been recorded since the installation process. The air scrubber $(3.5 \mathrm{~m} \times 3.6 \mathrm{~m} \times 3.9 \mathrm{~m}$; Figure 1$)$ is a counter-current plastic packed-bed (900 mm thick plastic honeycomb cores with a 1 $\mathrm{mm}$ mesh). The outlet air from the seven sections of the fattening building was extracted and directed to the air scrubber unit through a central depressurized duct (at 50 $\mathrm{Pa}$ ). According to the manufacturer' instructions the air scrubber is configured to operate at a maximum airflow rate of $2 \times 27400 \mathrm{~m}^{3} \cdot \mathrm{h}^{-1}$. This maximum flow rate corresponds to the recommended ventilation rate for the number of pigs in the seven sections $\left(70-80 \mathrm{~m}^{3} \cdot \mathrm{h}^{-1} \cdot \mathrm{pig}^{-1}\right)$. The empty bed residence time calculated with the maximum airflow (EBRT $=$ scrubber volume/scrubber airflow rate) is 3.2 seconds. The flow rate of the air entering the filter at a given time, which is automatically applied and recorded by the manufacturer's data logger, is linked to the flow rate of the outlet air from the pig building which depends on the outside temperature. In these conditions, the flow rate of the scrubber fluctuates resulting in fluctuating loading conditions. The air enters the air scrubber and passes through the plastic packed-bed and is continuously moistened by 16 water spraying nozzles (spray rate $=1 \mathrm{~m}^{3} \cdot \mathrm{h}^{-1}$ per nozzle). Finally, the air passes through a demister (thickness: $30 \mathrm{~cm}$ ) before leaving the air scrubber. The 

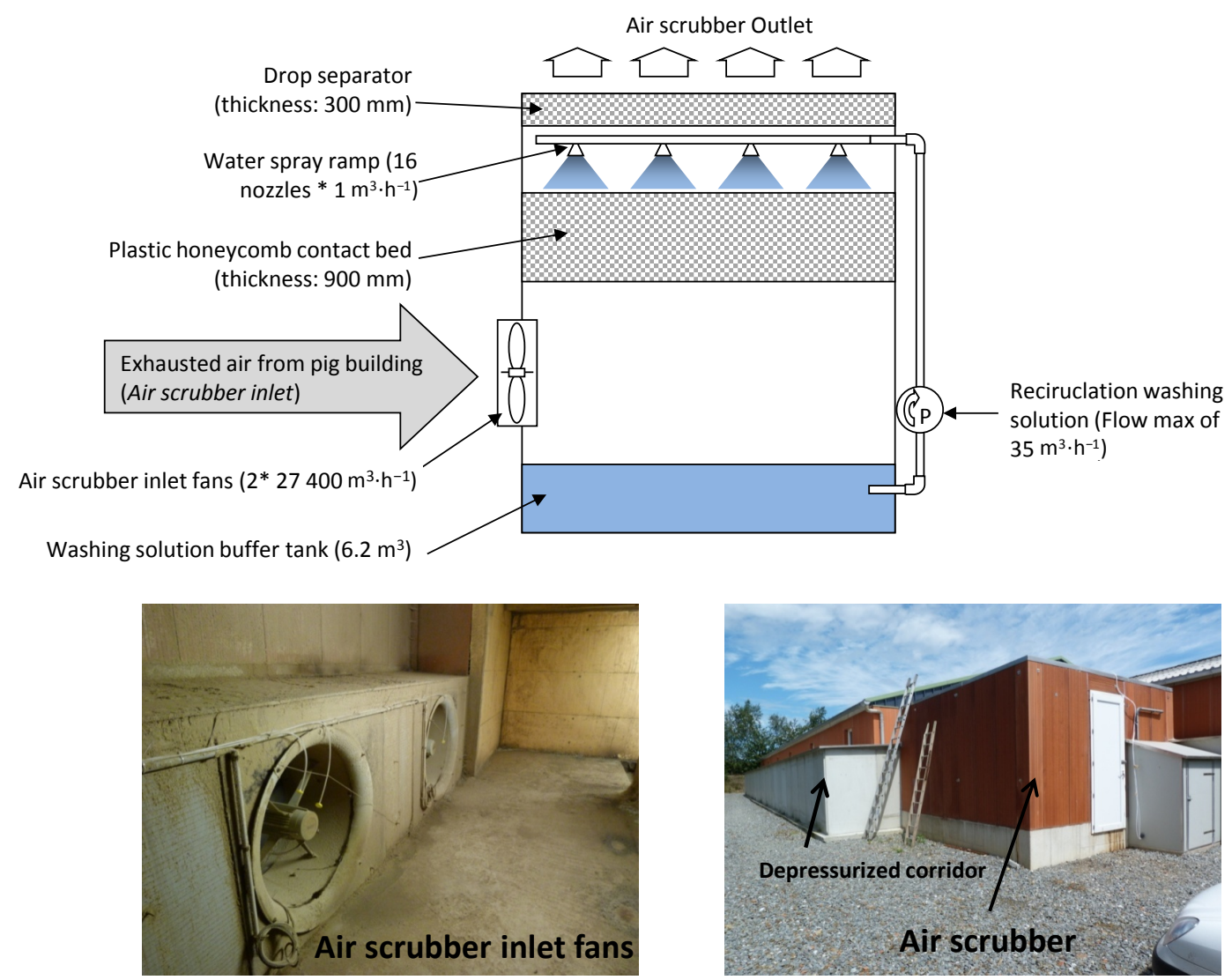

Figure 1. Characteristics of the air scrubber monitored on the farm.

washing water (tap water) is stored in a buffer tank $\left(6.2 \mathrm{~m}^{3}\right)$ and is continuously recirculated. A volume-controlled valve allows fresh water to be added automatically to supplement evaporated and discharged water. The discharge water is evacuated every six months to the slurry store and applied to arable land as fertilizer.

\section{3. $\mathrm{NH}_{3}$ and $\mathrm{N}_{2} \mathrm{O}$ Measurement}

The abatement of $\mathrm{NH}_{3}$ and the production of $\mathrm{N}_{2} \mathrm{O}$ by the air scrubber were estimated by measuring the concentration of the gases in the inlet and outlet air of the scrubber. The concentration of $\mathrm{NH}_{3}$ and $\mathrm{N}_{2} \mathrm{O}$ at the inlet was calculated as the mean of four sampling points located by the two scrubber inlet fans. The concentration at the outlet was calculated as the mean of three sampling points positioned on the diagonal of the scrubber outlet (Figure 2). This design was used to avoid the problem of potential preferential pathways. In addition, chimneys $(300 \mathrm{~mm}$ in diameter) equipped with a cap were used to protect the outlet sampling points from wind and rain (Figure 2). Each sampling point at the inlet and outlet was fitted with a 0.45 micron dust filter. The filters were replaced twice a week. The inlet and outlet air of the scrubber were continuously sampled by a system of pumps connected to a multiplexer (Secan 2800, EMS). The multiplexer connected a selected inlet or outlet monitoring point sequentially with a photoacoustic infrared gas analyzer (1412 Photoacoustic Field Gas Monitor, Innova 
Table 1. Main characteristics of the commercial air scrubber.

\begin{tabular}{lc}
\hline Number and type of animal & 750 fattening pigs \\
\hline Scrubbing principle & Counter current \\
Packing bed & Plastic honeycomb cores \\
Scrubber dimensions $(1 \times \mathrm{w} \times \mathrm{h})$ & $900 \mathrm{~mm}$ thick, $1 \mathrm{~mm} \mathrm{mesh}$ \\
Packing bed volume & $3.6 \mathrm{~m} \times 3.9 \mathrm{~m} \times 3.5 \mathrm{~m}$ \\
Specific surface area & $12.64 \mathrm{~m}^{3}$ \\
Maximum air flow rate & $125 \mathrm{~m}^{2} \cdot \mathrm{m}^{-3}$ \\
Maximum air speed & $54,800 \mathrm{~m}^{3} \cdot \mathrm{s}^{-1}$ \\
Minimum EBRT & $1.1 \mathrm{~m} \cdot \mathrm{s}^{-1}$ \\
Plastic demister & $3.2 \mathrm{~s}$ \\
Water recirculation & $0.3 \mathrm{~m}$ \\
Volume washing water tank & Permanent \\
Flow rate of recycling pump & $6.32 \mathrm{~m}^{3}$ \\
Spray density & $16 \mathrm{~m}^{3} \cdot \mathrm{h}^{-1}$ \\
Water discharge & $1.14 \mathrm{~m}^{3} \cdot \mathrm{m}^{-2} \cdot \mathrm{h}^{-1}$ \\
Loading of water tank & Every $6 \mathrm{months}$ \\
\hline
\end{tabular}

${ }^{\mathrm{a}}$ In dry clean condition; ${ }^{\mathrm{b}} \mathrm{Empty}$ bed residence time; calculated as air scrubber volume $\left(\mathrm{m}^{3}\right)$ divided by the maximum airflow rate $\left(\mathrm{m}^{3} \cdot \mathrm{s}^{-1}\right)$.

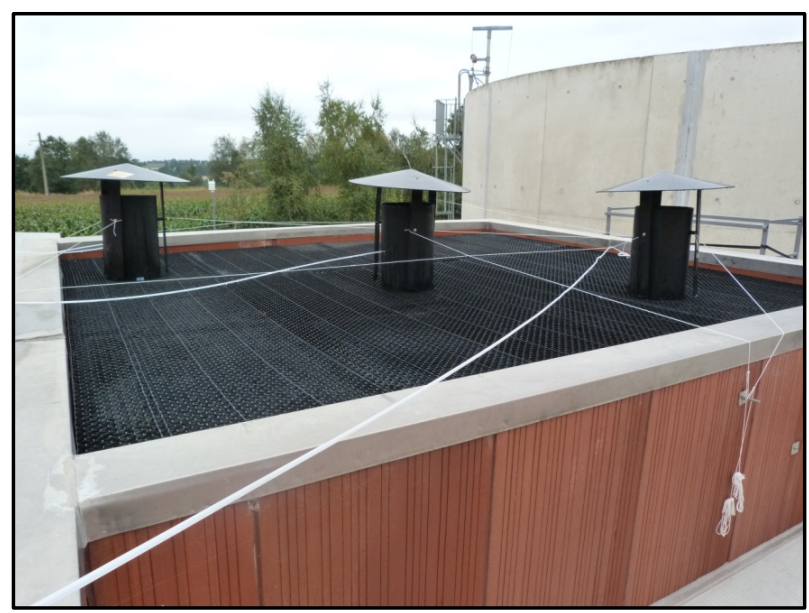

Figure 2. Chimney system for measurement of the concentration of $\mathrm{N}_{2} \mathrm{O}$ and $\mathrm{NH}_{3}$ at the outlet of the air scrubber.

Luma-Sense Technologies) with filter numbers UA973, UA982, UA985, UA969 and UA0988. The multiplexer was set up to connect one inlet or outlet air point every $8 \mathrm{~min}$ $30 \mathrm{~s}$, which corresponds to the time required to measure the concentration of five gases eight times. But, because of possible interference in the detection of $\mathrm{NH}_{3}$ and $\mathrm{N}_{2} \mathrm{O}$ due to the presence of other gases [21] [25] only the last three measurements (i.e. those 
made after six minutes) of the eight recorded measurements were averaged and used for data analysis. According to the measurement specifications provided by the manufacturer, the measurement uncertainty in air was $\pm 0.07 \mathrm{mg}\left[\mathrm{NH}_{3}\right] \mathrm{m}^{-3}$ and $0.027 \mathrm{mg}$ $\left[\mathrm{N}_{2} \mathrm{O}\right] \mathrm{m}^{-3}$. To check for possibly wrong quantification of gas concentrations by the IRphotoacoustic setup [25] the concentrations of $\mathrm{NH}_{3}$ were also measured with acid impingers, and the concentrations of $\mathrm{N}_{2} \mathrm{O}$ by gas chromatography (CG). To check concentrations of $\mathrm{NH}_{3}$, a fraction of the inlet and outlet air was continuously monitored for four days. The acid impingers were replaced at 24 hour intervals. The $\mathrm{NH}_{3}$ in the sampled air was trapped by passing through the impinger containing $50 \mathrm{~mL} \mathrm{H}_{2} \mathrm{SO}_{4}(1 \mathrm{~N})$ at a flow rate of $5 \mathrm{~L} \cdot \mathrm{min}^{-1}$. The ammonia in the total acid solution of the impinger was determined by alkaline distillation and titration. The concentration of $\mathrm{NH}_{3}$ in the sampled air was thus time averaged. To check the concentration of $\mathrm{N}_{2} \mathrm{O}$, approximately 15 $\mathrm{mL}$ of inlet and outlet air were randomly sampled with a gas syringe and stored in a 4 $\mathrm{mL}$ glass tube sealed with a rubber stopper. Over-pressure protected the contents of the vial in the case of imperfect sealing or possible pollution from ambient air. The concentration of $\mathrm{N}_{2} \mathrm{O}$ was determined with an Agilent $6890 \mathrm{~N} \mathrm{GC}$ chromatograph (Agilent Technologies, USA) equipped with an electron capture detector (ECD), a $3 \mathrm{~m} 1 / 8$ stainless steel pre-column filled with 90/100 Porapack $\mathrm{N}$ followed by a $4 \mathrm{~m} \mathrm{1/8}$ stainless steel column filled with $4 \mathrm{M}$ Porapack Q. Nitrogen was the carrier gas at $44 \mathrm{ml} \cdot \mathrm{min}^{-1}$ and temperatures of the column oven and ECD detectors were $70^{\circ} \mathrm{C}$ and $300^{\circ} \mathrm{C}$. The injection port temperature was $100^{\circ} \mathrm{C}$.

\subsection{Results and Statistical Analysis}

Based on the monitored concentration of gas and the recorded airflow rate, the efficiency of the air scrubber was assessed according to the $\mathrm{NH}_{3}$ loading rate, $\mathrm{NH}_{3}$ removal rate, and $\mathrm{NH}_{3}$ removal efficiency (\%) as described by Melse et al. [16]. $\mathrm{N}_{2} \mathrm{O}$ production was expressed either as the $\mathrm{N}_{2} \mathrm{O}$ production rate $\left(\mathrm{g}\left[\mathrm{N}_{2} \mathrm{O}\right] \mathrm{h}^{-1}\right)$ or as the percentage of $\mathrm{N}_{2} \mathrm{O}$ production.

Pearson's correlation coefficient ( $r$ ) was used to identify significant relationships between the $\mathrm{N}_{2} \mathrm{O}$ or $\mathrm{NH}_{3}$ emission rates and environmental and air scrubber working factors with a 95\% confidence interval $(\mathrm{P}<0.05, \mathrm{r}=0-0.25$ weak correlation, $0.251<\mathrm{r}$ $<0.500$ moderate correlation, $0.501<\mathrm{r}<0.750$ strong correlation, $0.751<\mathrm{r}<1.00$ strongest correlation).

\section{Results}

\subsection{Data Analysis}

$\mathrm{NH}_{3}$ concentrations obtained with the photoacoustic analyzer were of similar magnitude to those obtained using the acid impinger method taking the difference in the sensitivity of the two techniques into account. This similarity between the two methods was also observed by Dumont et al. [21]. Consequently, the photoacoustic analyzer was used to monitor all the $\mathrm{NH}_{3}$ concentrations. Likewise, no significant differences were found between measurements of the concentrations of $\mathrm{N}_{2} \mathrm{O}$ by GC-ECD and the pho- 
toacoustic analyzer. The response of the photoacoustic analyzer was sufficiently sensitive for the concentrations of $\mathrm{N}_{2} \mathrm{O}$ present at the inlet or outlet of the air scrubber.

Concerning the efficiency of the removal of $\mathrm{NH}_{3}$, the results were sometime negative due to significantly higher concentrations of $\mathrm{NH}_{3}$ at the outlet than at the inlet. Even though already observed [14] [26], these negative results accounted for $4 \%$ of the total results and were not retained for subsequent analyses. These results are questionable because no major differences in the scrubber operating parameters (outside temperature, airflow rate, $\mathrm{NH}_{3}$ inlet concentration) were found that could explain this phenomenon. Other erratic or outlier data due technical problems that are inherent to on-site measurement campaigns, e.g. instrument failure; malfunction of the measuring equipment (pump, analyzer etc.) were also excluded from subsequent analyses. The results discussed hereafter are based on data from the infrared analyzer after the exclusion of the previously described values. Table 2 summarizes these results.

\subsection{Air Scrubber Operating Parameters}

Over the study period, the airflow rate of the air scrubber ranged from 37,538 to 54,800 $\mathrm{m}^{3} \cdot \mathrm{h}^{-1}$ with an overall average of $45,708 \mathrm{~m}^{3} \cdot \mathrm{h}^{-1}$. Fluctuations in the air scrubber flow rate closely mirrored fluctuations in the outside temperature (Figure 3 ), which ranged

Table 2. Summary of air scrubber operating parameters, and $\mathrm{NH}_{3}$ and $\mathrm{N}_{2} \mathrm{O}$ emissions over the 2 months of monitoring of the commercial air scrubber.

\begin{tabular}{|c|c|c|c|c|}
\hline & Min & Mean & Max & $\mathrm{SD}$ \\
\hline Outside Temperature $\left({ }^{\circ} \mathrm{C}\right)$ & 5.6 & 13.7 & 22.8 & 3.3 \\
\hline Inlet Temperature $\left({ }^{\circ} \mathrm{C}\right)$ & 9.2 & 15.4 & 21.8 & 2.5 \\
\hline Scrubber airflow rate $\left(\mathrm{m}^{3} \cdot \mathrm{h}^{-1}\right)$ & 37,538 & 45,708 & 54,800 & 4297 \\
\hline Air speed $\left(\mathrm{m} \cdot \mathrm{s}^{-1}\right)$ & 0.7 & 0.9 & 1.1 & 0.1 \\
\hline $\operatorname{EBRT}(\mathrm{s})$ & 3.2 & 3.9 & 4.7 & 0.4 \\
\hline \multicolumn{5}{|l|}{$\mathrm{NH}_{3}$} \\
\hline Inlet concentration ${ }^{1}\left(\mathrm{mg} \cdot \mathrm{m}^{-3}\right)$ & 7.5 & 12.1 & 20.6 & 1.2 \\
\hline Outlet concentration ${ }^{2}\left(\mathrm{mg} \cdot \mathrm{m}^{-3}\right)$ & 5.2 & 8.0 & 13.6 & 1.3 \\
\hline $\mathrm{NH}_{3}$ loading rate $\left(\mathrm{g}\left[\mathrm{NH}_{3}\right] \mathrm{h}^{-1}\right)$ & 323 & 552 & 1035 & 81 \\
\hline $\mathrm{NH}_{3}$ loading rate $\left(\mathrm{g}\left[\mathrm{NH}_{3}\right] \mathrm{m}^{-3} \cdot \mathrm{h}^{-1}\right)$ & 26 & 44 & 82 & 6.4 \\
\hline $\mathrm{NH}_{3}$ removal rate $\left(\mathrm{g}\left[\mathrm{NH}_{3}\right] \mathrm{h}^{-1}\right)$ & 5.6 & 187 & 535 & 68 \\
\hline $\mathrm{NH}_{3}$ removal rate $\left(\mathrm{g}\left[\mathrm{NH}_{3}\right] \mathrm{m}^{-3} \cdot \mathrm{h}^{-1}\right)$ & 0.4 & 15 & 42 & 5.4 \\
\hline $\mathrm{NH}_{3}$ removal efficiency (\%) & 1.4 & 33.5 & 57.1 & 10.7 \\
\hline \multicolumn{5}{|l|}{$\mathrm{N}_{2} \mathrm{O}$} \\
\hline Inlet concentration ${ }^{1}\left(\mathrm{mg} \cdot \mathrm{m}^{-3}\right)$ & 0.24 & 0.55 & 1.06 & 0.17 \\
\hline Outlet concentration $^{2}\left(\mathrm{mg} \cdot \mathrm{m}^{-3}\right)$ & 0.61 & 0.93 & 1.52 & 0.16 \\
\hline $\mathrm{N}_{2} \mathrm{O}$ production rate $\left(\mathrm{g}\left[\mathrm{N}_{2} \mathrm{O}\right] \mathrm{h}^{-1}\right)$ & 5.1 & 17.6 & 31.6 & 3.9 \\
\hline
\end{tabular}

(1) Average value of 4 sampling points (2) Average of 3 sampling points. 


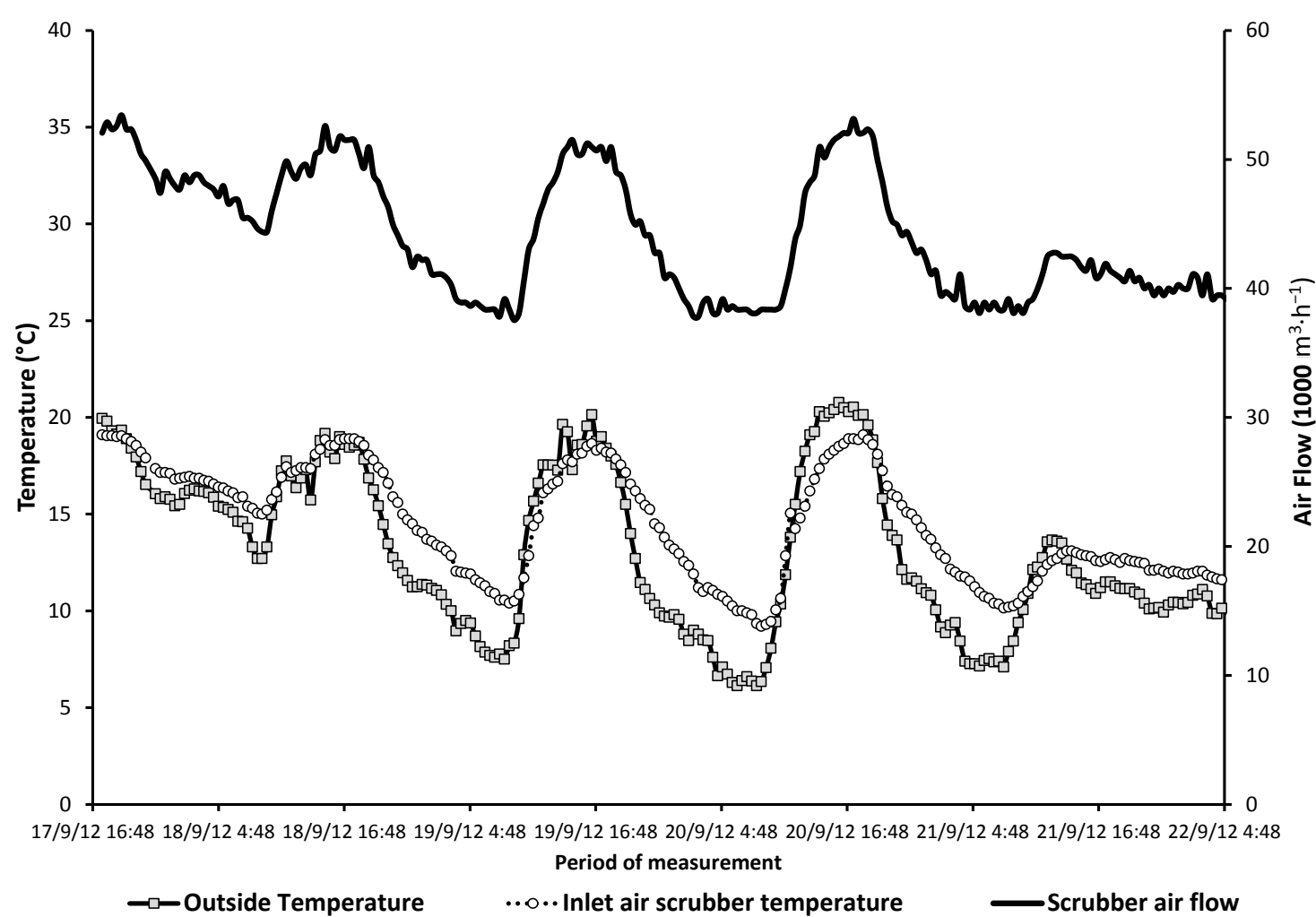

Figure 3. Fluctuations in outside temperature, inlet air scrubber temperature and air flow rate.

from $5.6^{\circ} \mathrm{C}$ to $22.8^{\circ} \mathrm{C}$. The outside temperature impacted the ambient temperature of the pig room, which ranged from $23.5^{\circ} \mathrm{C}$ to $28.5^{\circ} \mathrm{C}$. Similarly, the temperature of the inlet air of the scrubber fluctuated over the study period from $9.2^{\circ} \mathrm{C}$ to $21.8^{\circ} \mathrm{C}$. This trend was expected as the flow rate to the air scrubber corresponds to the total exhaust air from the seven sections of the piggery, which are regulated individually depending on the outside temperature. Consequently, the EBRT in the scrubber ranged from 3.2 to 4.7 seconds with an overall average of 3.9 seconds and the air speed ranged from 0.7 to $1.1 \mathrm{~m} \cdot \mathrm{s}^{-1}$ with an overall average of $0.9 \mathrm{~m} \cdot \mathrm{s}^{-1}$. The fluctuations of the airflow rate meant that the air scrubber operated under fluctuating $\mathrm{NH}_{3}$ loading conditions, as reported in the study of Melse et al. [17].

\subsection{Efficiency of Ammonia Removal}

Figure 4 partially illustrates fluctuations in the concentration of $\mathrm{NH}_{3}$ at the scrubber inlet, outside temperature, and airflow rate.

The concentration of $\mathrm{NH}_{3}$ at the inlet fluctuated widely from 7.5 to $20.6 \mathrm{mg}\left[\mathrm{NH}_{3}\right]$ $\mathrm{m}^{-3}$ with an overall average of $12.1 \mathrm{mg}\left[\mathrm{NH}_{3}\right] \mathrm{m}^{-3}$. The concentration of $\mathrm{NH}_{3}$ at the outlet mirrored this trend and fluctuated between 5.2 and $13.6 \mathrm{mg}\left[\mathrm{NH}_{3}\right] \mathrm{m}^{-3}$ with an overall average of $8.0 \mathrm{mg}\left[\mathrm{NH}_{3}\right] \mathrm{m}^{-3}$. The concentrations of $\mathrm{NH}_{3}$ at the inlet and outlet are in the same order of magnitude as those reported in the literature [17] [27].

The fluctuations in the concentrations of $\mathrm{NH}_{3}$ at the inlet combined with the fluctuations in the airflow rate resulted in fluctuations in the $\mathrm{NH}_{3}$ loading rate and in the $\mathrm{NH}_{3}$ 


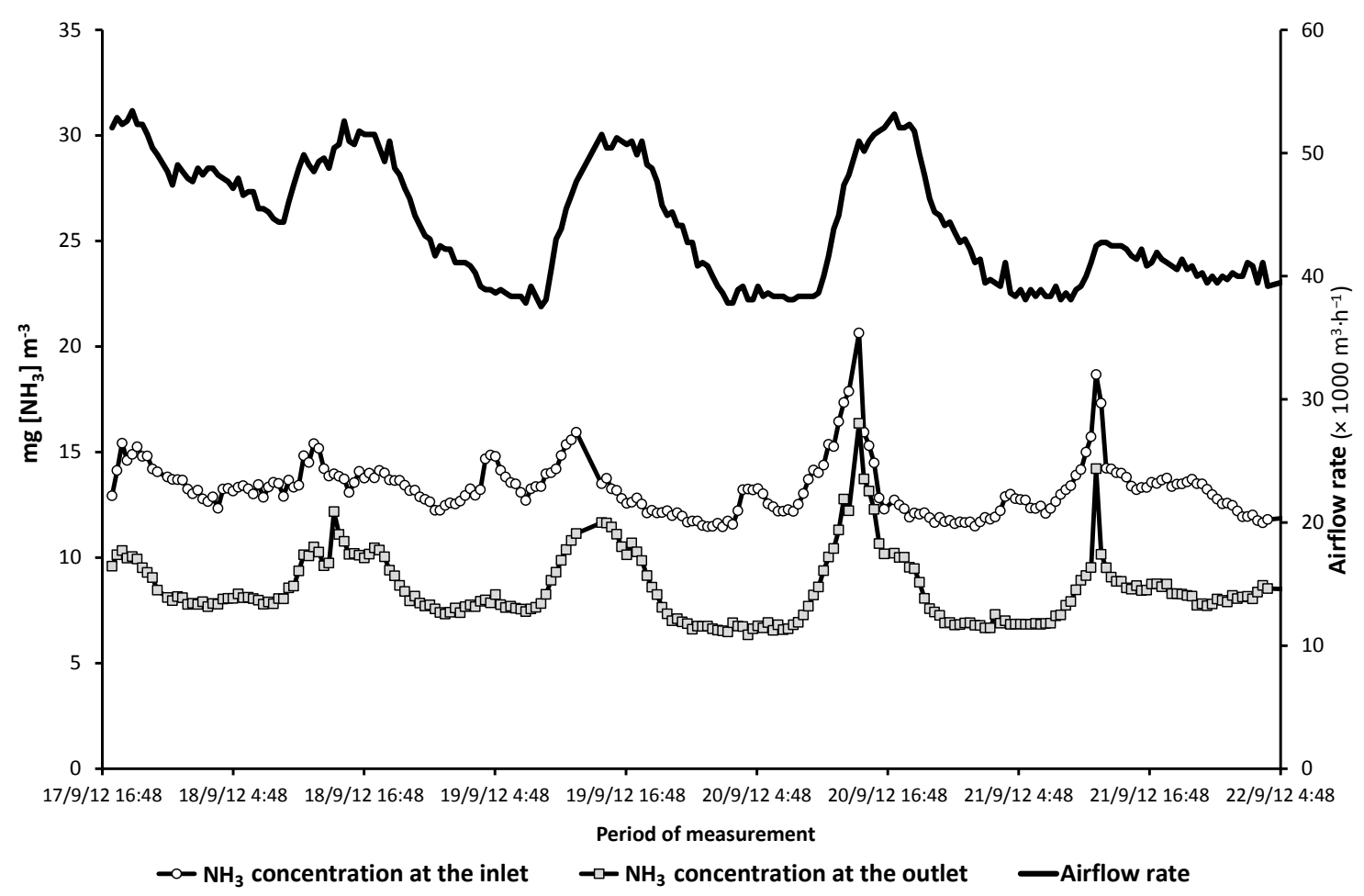

Figure 4. Fluctuations in the concentrations of ammonia at the inlet and outlet of the scrubber and in the air flow rate during air scrubber monitoring.

removal rate. The $\mathrm{NH}_{3}$ loading rate ranged from 323 to $1035 \mathrm{~g}\left[\mathrm{NH}_{3}\right] \mathrm{h}^{-1}$ with an overall average of $552 \mathrm{~g}\left[\mathrm{NH}_{3}\right] \mathrm{h}^{-1}$. The $\mathrm{NH}_{3}$ removal rate ranged from 5.5 and $535 \mathrm{~g}\left[\mathrm{NH}_{3}\right]$ $\mathrm{h}^{-1}$ with an overall average of $187 \mathrm{~g}^{2}\left[\mathrm{NH}_{3}\right] \mathrm{h}^{-1}$.

Based on these data, the $\mathrm{NH}_{3}$ removal efficiency ranged from $1.4 \%$ to $57 \%$ with an overall average of $33 \%$. The rate of $\mathrm{NH}_{3}$ removal by the scrubber recorded is this study is thus lower than the $70 \%-90 \%$ range usually cited when a scrubber is recommended for the reduction of ammonia produced in livestock farming [11] [14]. However, the $33 \%$ removal found is our study is in agreement with the results of other French experiments on commercial scrubbers set up to reduce odours [19] [23]. It is well established that the efficiency of air scrubbers in removing $\mathrm{NH}_{3}$ is strongly dependent on the characteristics of the equipment (ammonia loading rate, airflow rate, etc.) and the operating conditions (design, maintenance, renewal of washing water, etc.) [14] [17] [19] [20].

Some general trends emerged from our monitoring of the air scrubber over the whole period. Over time, our results showed an increase in the concentrations of $\mathrm{NH}_{3}$ at the inlet and the concentrations of $\mathrm{NH}_{3}$ ammonia at the outlet with an increase in the airflow rate. This resulted in an increase in the $\mathrm{NH}_{3}$ loading rate, a reduction in the $\mathrm{NH}_{3}$ removal rate $\left(\mathrm{g} \cdot \mathrm{h}^{-1}\right)$ which in turn reduced the efficiency of the $\mathrm{NH}_{3}$ removal rate (\%) with an increase in the air scrubber flow rate (Figure 5).

Statistical analysis (Pearson's test, $\mathrm{P}=0.05$ ) of the overall data highlighted some interesting facts. Our results indicated a significant but weak positive effect of airflow rate 


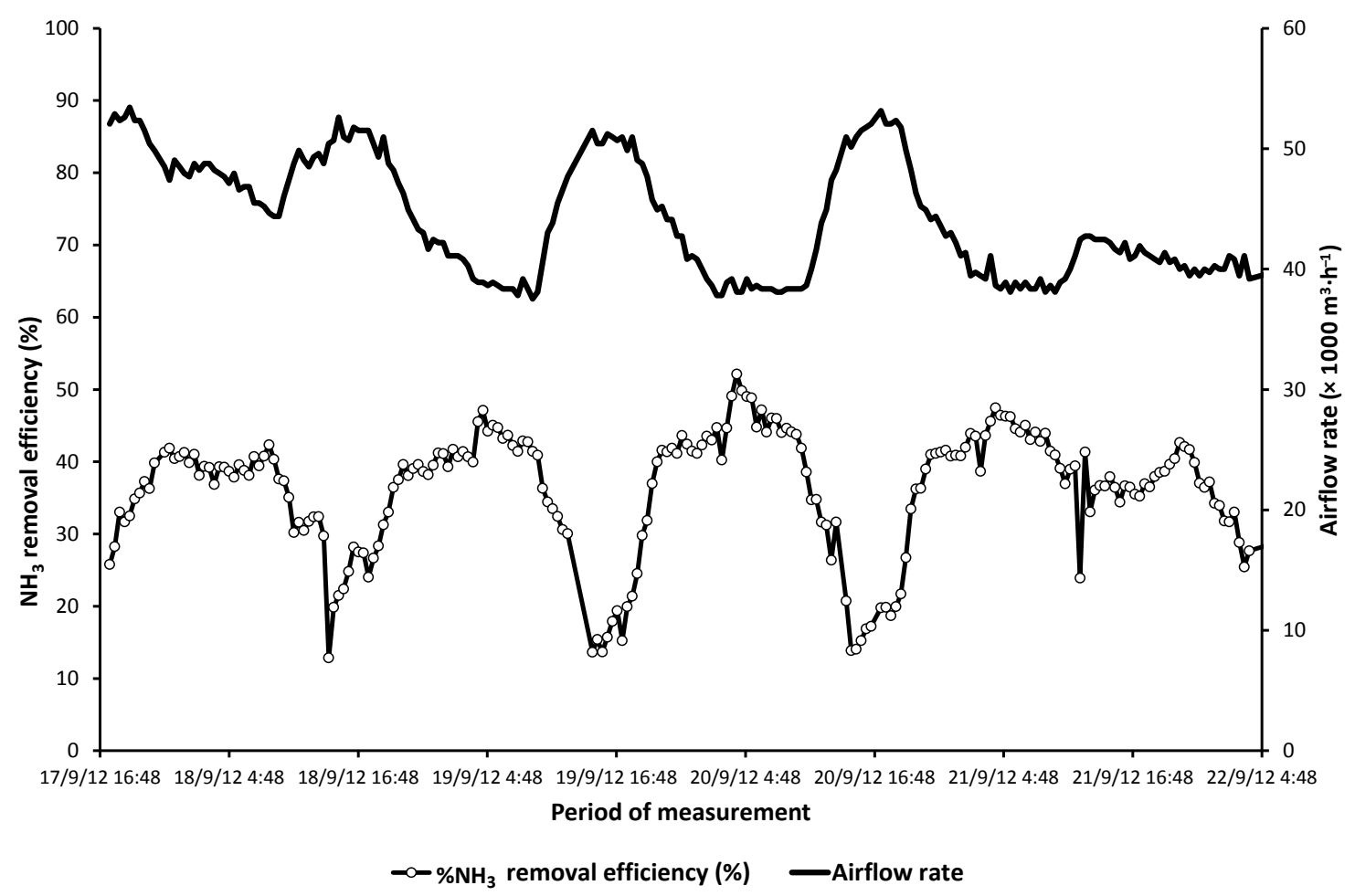

Figure 5. Fluctuations in $\mathrm{NH}_{3}$ removal rate (\%) and in the air flow rate during air scrubber monitoring.

on the concentration of $\mathrm{NH}_{3}$ at the inlet $(\mathrm{r}=0.22, \mathrm{P}<0.05)$. This does not correspond to the effects observed by Melse et al. [17] who observed a daily pattern between the airflow rate and the concentration of $\mathrm{NH}_{3}$ at the inlet due to the activity of the pigs, which influenced $\mathrm{NH}_{3}$ emissions. In the same way, the strong positive link between the efficiency of $\mathrm{NH}_{3}$ removal and the concentration of $\mathrm{NH}_{3}$ at the inlet observed in other studies [27] [28] was not observed in our study $(\mathrm{r}=0.21, \mathrm{P}<0.05)$. Our result might be due to the central ventilation system, which mixed the exhaust air from several sections of the piggery, thereby reducing fluctuations in the concentration of $\mathrm{NH}_{3}$ at the inlet and hence in fewer fluctuations in the loading rate of $\mathrm{NH}_{3}$ [29]. Another explanation for these different results might be the deposits of dust in the duct that could "smooth" the concentrations at the inlet. Indeed, a significant proportion, (up to 40\%) of the $\mathrm{NH}_{3}$ in the exhausted air from the piggery could be fixed on dust [21] [30]. The $\mathrm{NH}_{3}$ loading rate is closely correlated with the outside temperature and the airflow rate $(\mathrm{r}=0.7, \mathrm{P}<$ 0.05) meaning that more $\mathrm{NH}_{3}$ enters the air scrubber. An increase in the outside temperature thus implies an increase in the airflow rate to maintain satisfactory conditions in the piggery. In turn, this affects $\mathrm{NH}_{3}$ emissions in the pig rooms [5]. However, in our study, there was a very weak correlation between $\mathrm{NH}_{3}$ removal rate and outside temperature or airflow rate $(\mathrm{r}<0.1, \mathrm{P}<0.05)$. The parameters that most strongly influenced $\mathrm{NH}_{3}$ removal efficiency (\%) were outside temperature $(\mathrm{r}=-0.5, \mathrm{P}<0.05)$ and airflow rate, which determined the air contact time between $\mathrm{NH}_{3}$ and the washing solution $(\mathrm{r}=-0.4, \mathrm{P}<0.05)$. An increase in the airflow rate reduced the contact time (EBRT) between the air and the washing solution thereby reducing the mass transfer of 
$\mathrm{NH}_{3}$ from the air to the water. This is consistent with the results of previous studies, underlining the link between the efficiency of the air scrubber and the air-liquid contact time [19] [20] [23]. However, according to the $\mathrm{NH}_{3}$ removal rate (figure and statistical data), one could assume that the commercial air scrubber parameters only enable the transfer of a certain mass of $\mathrm{NH}_{3}$. Beyond this $\mathrm{NH}_{3}$ mass value, the $\mathrm{NH}_{3}$ is not transferred to the washing solution. This maximum transfer value is thus reduced by an increase in airflow, which reduces the contact time needed for the transfer of $\mathrm{NH}_{3}$. All these factors contributed to the reduction of $\mathrm{NH}_{3}$ removal efficiency (\%).

Other parameters that could influence the efficiency of $\mathrm{NH}_{3}$ removal are the characteristics of the washing water (not measured in this study). The fluctuations in the air scrubber in removing $\mathrm{NH}_{3}$ could be associated with the accumulation of ammonia and nitrate/nitrite in the solution produced over time [31]. Melsea and Ogink [14] (2005) reported that up to $90 \%$ of the ammonia-N removed was discharged or accumulated in the water as ammonium and nitrate. According to different authors [14] [15] [32], the accumulation of nitrogen compounds in washing water could modify the equilibrium between the concentration of ammonia in the outlet air and the concentration of dissolved ammonia in the water [17]. Such an equilibrium is usually influenced by fluctuations in the composition of the air and of the water, which occurs when the air scrubber is overloaded or when the flow rate of the discharge water is set too low [17] [20].

From our study, it appears that the air scrubber installed at a commercial farm to reduce the odours emitted by the exhausted air from the piggery was less effective in reducing the $\mathrm{NH}_{3}$ than values normally cited in the literature. It would be possible to enhance the removal of $\mathrm{NH}_{3}$ by reducing the accumulation of nitrogen in the washing solution [17] [19] without modifying the operating parameters (airflow rate, water flow rate) of the air scrubber used in this experiment. This could be done by discharging water [26]. However, Guingand [33] observed no difference in the ammonia reduction rate between an option in which the washing water was emptied four times and a no emptying option. Another possible way to enhance the removal of $\mathrm{NH}_{3}$ would be to add a biological treatment step of the washing water [22] [34]. It would also be useful to include a control and monitoring process of the washing water. This could be achieved by installing an electrical conductivity meter [14] which is positively linked to the ammonia in solution [19]. From a scientific viewpoint, identifying the parameters responsible for the low $\mathrm{NH}_{3}$ removal would require a more in-depth analysis than was planned in the present study. In particular, analyzing the washing water would be necessary.

\section{4. $\mathrm{N}_{2} \mathrm{O}$ Production}

As shown in Figure 6, the concentration of $\mathrm{N}_{2} \mathrm{O}$ at the air scrubber outlet was systematically higher than that measured at the inlet. The concentration of $\mathrm{N}_{2} \mathrm{O}$ at the inlet ranged from 0.24 to $1.06 \mathrm{mg}\left[\mathrm{N}_{2} \mathrm{O}\right] \mathrm{m}^{-3}$ with an overall average of $0.55 \mathrm{mg}\left[\mathrm{N}_{2} \mathrm{O}\right] \mathrm{m}^{-3}$. The concentration of $\mathrm{N}_{2} \mathrm{O}$ at the outlet fluctuated between 0.61 and $1.52 \mathrm{mg}\left[\mathrm{N}_{2} \mathrm{O}\right] \mathrm{m}^{-3}$ with an overall average of $0.93 \mathrm{mg}\left[\mathrm{N}_{2} \mathrm{O}\right] \mathrm{m}^{-3}$. The statistical analysis of all the data revealed a significant difference $(\mathrm{P}<0.05)$ between the concentration of $\mathrm{N}_{2} \mathrm{O}$ at the inlet 


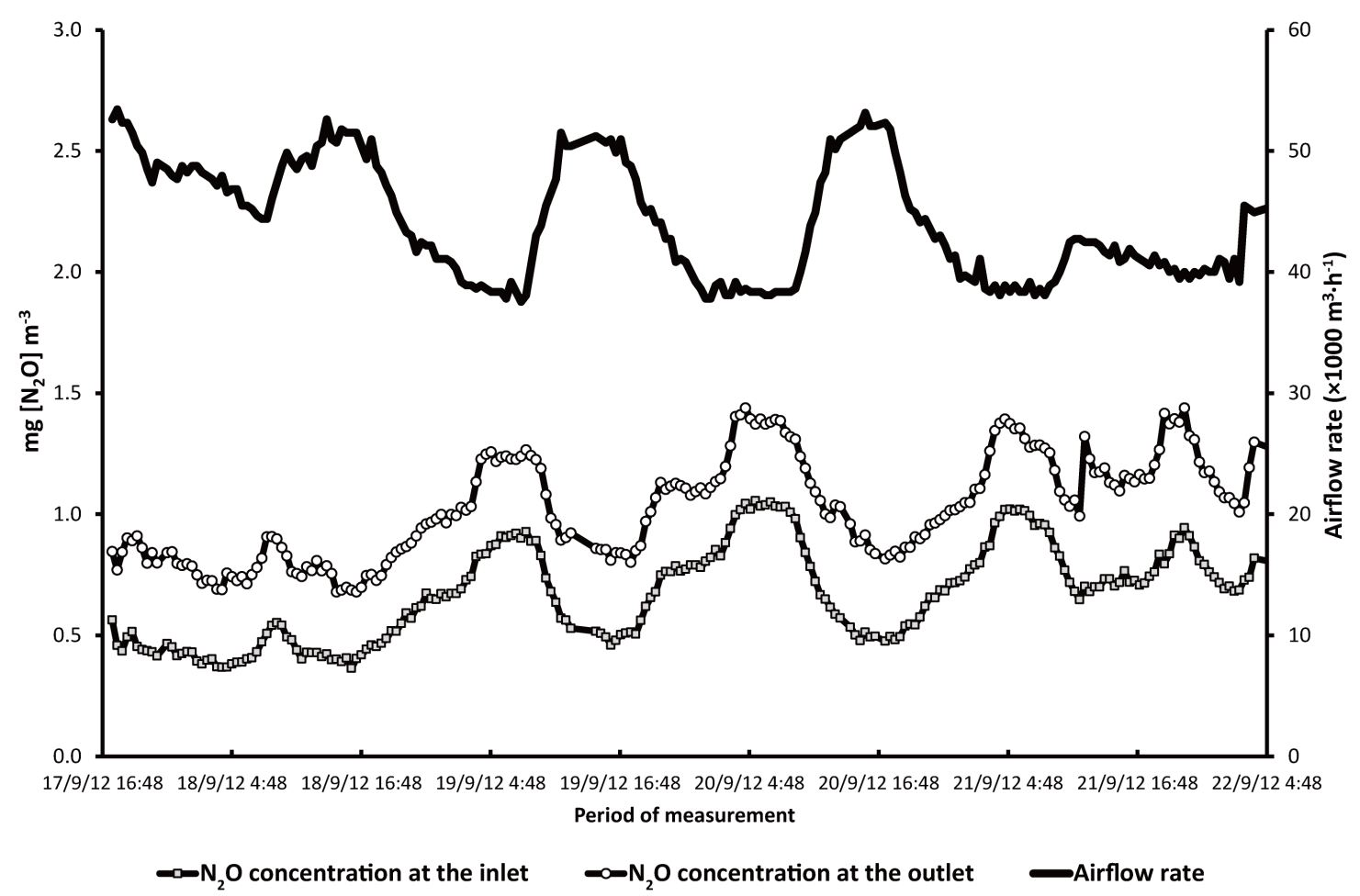

Figure 6. Fluctuations in the concentration of $\mathrm{N}_{2} \mathrm{O}$ at the inlet and outlet and in the air flow rate during monitoring of the air scrubber.

and at the outlet of the air scrubber. Our results indicate production of $\mathrm{N}_{2} \mathrm{O}$ by the air scrubber ranging from 14 to $233 \%$ with an overall average of $78 \%$ compared to the concentration in the air at the inlet. $\mathrm{N}_{2} \mathrm{O}$ production fluctuated from 5.1 to $31.6 \mathrm{~g}\left[\mathrm{~N}_{2} \mathrm{O}\right]$ $\mathrm{h}^{-1}$ with an overall average of $17.6 \mathrm{~g}\left[\mathrm{~N}_{2} \mathrm{O}\right] \mathrm{h}^{-1}$.

These results confirm the production of $\mathrm{N}_{2} \mathrm{O}$ reported in other studies [17] [27] with similar air scrubbers to reduce ammonia from exhausted air originating from pig buildings. The production of $\mathrm{N}_{2} \mathrm{O}-\mathrm{N}$ observed in this study corresponds to an average of $5 \%$ of $\mathrm{NH}_{3}-\mathrm{N}$ eliminated. This mean value is equivalent to that reported by Melse et al. [17] for an average scrubber efficiency of $70 \%$ for $\mathrm{NH}_{3}$. Figure 7 clearly reveals fluctuations in the production of $\mathrm{N}_{2} \mathrm{O}-\mathrm{N}\left(\% \mathrm{NH}_{3}-\mathrm{N}\right.$ removal) with fluctuations in the outside temperature and in the airflow rate. An increase in the outside temperature and in the airflow rate resulted in an increase in $\mathrm{N}_{2} \mathrm{O}-\mathrm{N}$ production. Statistical analysis revealed a strong statistical correlation between $\mathrm{N}_{2} \mathrm{O}$ production $\left(\mathrm{g}\left[\mathrm{N}_{2} \mathrm{O}\right] \mathrm{h}^{-1}\right)$ and air temperature (outside or inlet air, $\mathrm{r}=0.6, \mathrm{P}<0.05$ ), airflow rate and implicitly the EBRT and air speed $(\mathrm{r}=0.6, \mathrm{P}<0.05)$ and $\mathrm{NH}_{3}$ loading rate $(\mathrm{r}=0.5, \mathrm{P}<0.05)$.

Several authors assume that $\mathrm{N}_{2} \mathrm{O}$ production in the air scrubber is due to biological degradation (nitrification/denitrification) of the nitrogen present in the washing solution by a biomass developing in the packed-bed plastic or in the washing solution due to dust deposition [17] [21] [31]. $\mathrm{N}$ is biologically degraded by ammonia-oxidizing bacteria such as Nitrosomonas and by nitrite oxidizing bacteria such as Nitrobacter and Nitrospira [35]. The carbon required for nitrification can be obtained from the organic 


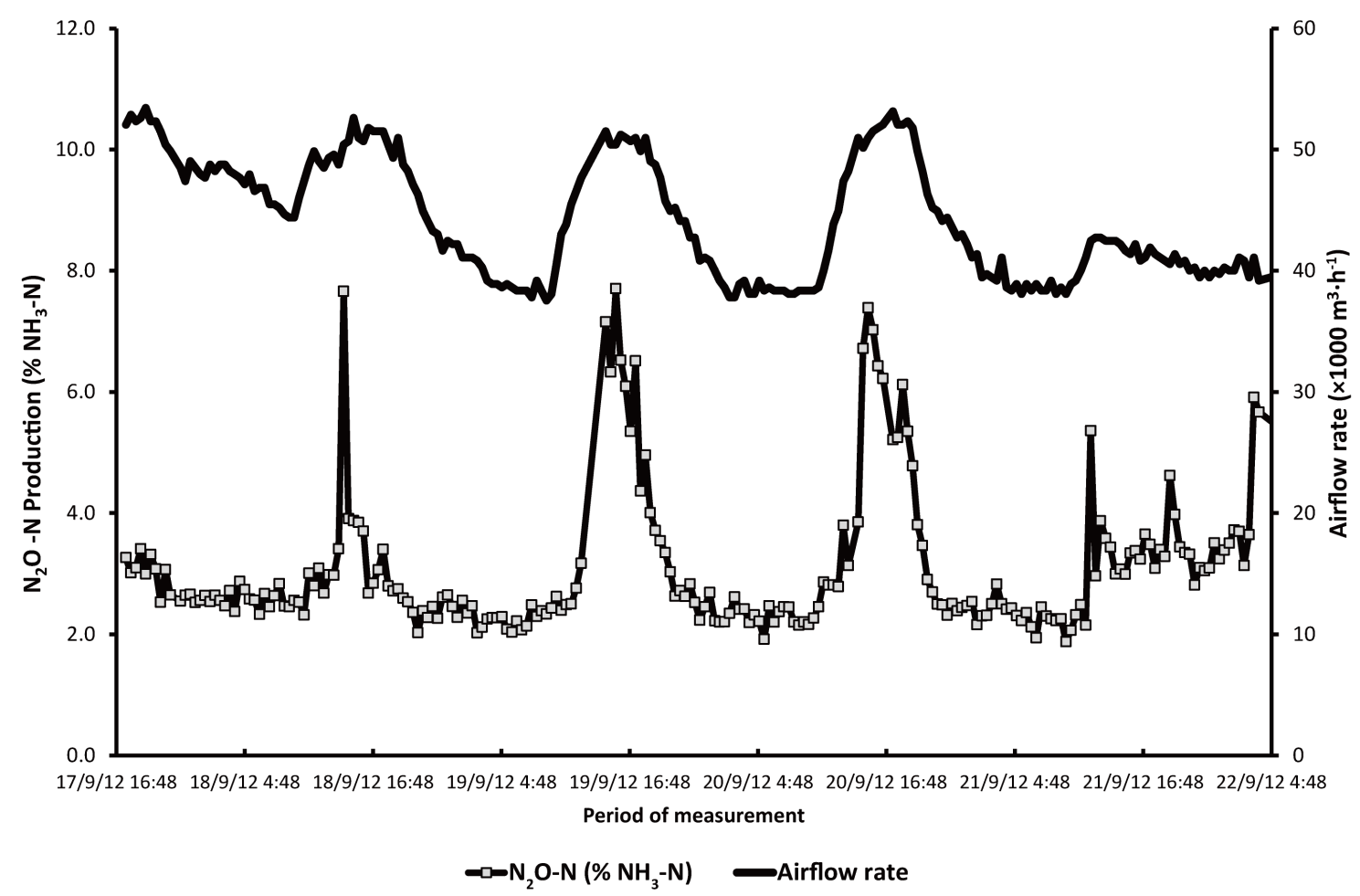

Figure 7. Fluctuations in $\mathrm{N}_{2} \mathrm{O}-\mathrm{N}$ production $\left(\% \mathrm{NH}_{3}-\mathrm{N}\right.$ removal) and air flow rate during monitoring of the air scrubber.

materials in the dust particles entering the air scrubber. In general, complete nitrification and denitrification requires the control of $\mathrm{pH}$, temperature, substrate and chemical oxygen demand (COD), dissolved oxygen, etc. as well as preventing the accumulation of inhibitory metabolites such as free ammonia. As mentioned above, up to $90 \%$ of the $\mathrm{NH}_{3}$ removed from piggery air was discharged or accumulated in the washing solution and hence available for bacterial oxidation to nitrite $\left(\mathrm{NO}_{2}^{-}\right)$and subsequently from nitrite to nitrate $\left(\mathrm{NO}_{3}^{-}\right)$. It is therefore likely that high concentrations of $\mathrm{NH}_{4}^{+}$and $\mathrm{NO}_{2}^{-}$in the washing solution affected the activity of Nitrosomonas and Nitrobacter. Moreover, $\mathrm{N}_{2} \mathrm{O}$ production is highly dependent on biodegradable carbon, which is expressed as a low COD:N ratio during denitrification [22]. This implies that fluctuations in the $\mathrm{NH}_{3}$ loading rate of the air scrubber might have an influence on the measured $\mathrm{N}_{2} \mathrm{O}$ production rate, as a change in $\mathrm{NH}_{3}$ loading rate could change the COD:N ratio. A too low COD: $\mathrm{N}$ ratio may increase the production of $\mathrm{N}_{2} \mathrm{O}$ during denitrification. Finally, other parameters can also influence the production of $\mathrm{N}_{2} \mathrm{O}$ including the temperature of the air to be treated, and the $\mathrm{NH}_{4}^{+}$content, temperature, level of oxygen dissolved and $\mathrm{pH}$ of the washing water [19] [20].

However, based on our results alone, it is difficult to establish a link between $\mathrm{N}_{2} \mathrm{O}$ production and the operating conditions of the scrubber or the climatic conditions, as these factors are inter-correlated [17]. At commercial scale, the washing dynamics is complex because the physical-chemical reactions and biological reactions occur simultaneously and due to the different media (gas, water, biofilm, and solids) involved. In 
the same way as for the efficiency of $\mathrm{NH}_{3}$ removal, data on the washing solution during the monitoring period would be required for analysis.

A complete understanding and interpretation of the data could be done with certitude only by making the $\mathrm{N}$ balance of the process (including the concentrations of $\mathrm{NO}_{2}^{-}$and $\mathrm{NH}_{4}^{+}$as they may inhibit nitrifying bacteria depending on $\mathrm{pH}$ value). However, this was not possible because of the configuration of the commercial air scrubber.

\section{Conclusions}

The aim of this study was to assess the reduction in $\mathrm{NH}_{3}$ emissions and the possible production of $\mathrm{N}_{2} \mathrm{O}$ by a commercial air scrubber installed to reduce odours from a building housing fattening pigs. The results of a 2 month period of monitoring of a building holding 750 pigs indicated that with the operating parameters of the scrubber concerned (airflow, design), the reduction in $\mathrm{NH}_{3}$ emissions was about 33\%, which was much lower than the $70 \%-90 \%$ reported in the literature. Statistical analysis (Pearson's test) indicated that the parameters defining the air contact time (airflow, air speed, EBRT) between $\mathrm{NH}_{3}$ and the washing solution had the strongest influence on the efficiency of $\mathrm{NH}_{3}$ removal (\%). Another parameter that could influence the efficiency of $\mathrm{NH}_{3}$ removal is the composition of the washing solution (not measured in this study). The instability of the results achieved by the scrubber could be associated with the accumulation of ammonia and nitrate/nitrite in solution produced over time.

This study supported the findings of other studies concerning the production of $\mathrm{N}_{2} \mathrm{O}$,

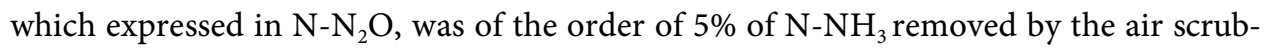
ber. This $\mathrm{N}_{2} \mathrm{O}$ is certainly produced by the biological degradation that takes place inside the air scrubber by nitrification/denitrification of the nitrogen present in the washing solution. The biomass that develops in the packed-bed plastic or in the washing solution due to dust deposition is certainly the cause of this biological activity. $\mathrm{N}_{2} \mathrm{O}-\mathrm{N}$ production (\% $\mathrm{NH}_{3}-\mathrm{N}$ removal) was strongly correlated with fluctuations in the outside temperature and in the airflow rate. An increase in the outside temperature and airflow rate increased $\mathrm{N}_{2} \mathrm{O}-\mathrm{N}$ production.

This study shows that the use of air scrubbers to reduce odours for $\mathrm{NH}_{3}$ regulatory purposes requires some modifications to optimize the efficiency of $\mathrm{NH}_{3}$ removal and to limit the production of $\mathrm{N}_{2} \mathrm{O}$. This could be achieved, for example, by setting up a control and monitoring process for the washing water, for example an electrical conductivity meter positively linked to the ammonia in the washing solution. From a scientific viewpoint, exploration of the parameters responsible for the low rate of $\mathrm{NH}_{3}$ removal and $\mathrm{N}_{2} \mathrm{O}$ production requires more comprehensive analysis than that is planned in the present study, in particular, analysis of the washing water. In conclusion, this study shows that air scrubbers need to be characterized under farm conditions to avoid overestimating the expected efficiency in reducing $\mathrm{NH}_{3}$ and to control the production of $\mathrm{N}_{2} \mathrm{O}$, when the target is to reduce odours. 


\section{Acknowledgements}

The authors wish to acknowledge the financial support received from the European Regional Development Fund (management under the Atlantic Area Transnational Programme) for the BATFARM Interreg-Atlantic Area Project (2009-1/071) entitled "Evaluation of best available techniques to decrease air and water pollution in animal farms". The authors would like to thank the livestock farmer for proving access to his farm as well as technical assistance.

\section{References}

[1] Steinfeld, H., Gerber, P., Wassenaar, T., Castel, V., Rosales, M. and de Haan, C. (2006) Livestock's Long Shadow-Environmental Issues and Options. FAO, Rome.

[2] Chadwick, D., Sommer, S., Thorman, R., Fangueiro, D., Cardenas, L., Amon, B. and Misselbrook, T. (2011) Manure Management: Implications for Greenhouse Gas Emissions. Animal Feed Science and Technology, 166-167, 514-531. http://dx.doi.org/10.1016/j.anifeedsci.2011.04.036

[3] Webb, J., Sommer, S., Kupper, T., Groenestein, K., Hutchings, N., Eurich-Menden, B., Rodhe, L., Misselbrook, T. and Amon, B. (2012) Emissions of Ammonia, Nitrous Oxide and Methane during the Management of Solid Manures. In: Lichtfouse, E., Ed., Agroecology and Strategies for Climate Change, Springer, Netherlands, 67-107. http://dx.doi.org/10.1007/978-94-007-1905-7_4

[4] Hamon, L., Andrès, Y. and Dumont, E. (2012) Aerial Pollutants in Swine Buildings: A Review of Their Characterization and Methods to Reduce Them. Environmental Science \& Technology, 46, 12287-12301. http://dx.doi.org/10.1021/es3025758

[5] Philippe, F.-X., Cabaraux, J.-F. and Nicks, B. (2011) Ammonia Emissions from Pig Houses: Influencing Factors and Mitigation Techniques. Agriculture, Ecosystems \& Environment, 141, 245-260. http://dx.doi.org/10.1016/j.agee.2011.03.012

[6] UNECE (1999) Protocol to the 1979 Convention on Long-Range Transboundary Air Pollution to Abate Acidification, Eutrophication and Ground-Level Ozone (Gothenburg Protocol).

[7] EC (2001) Directive 2001/81/EC of the European Parliament and of the Council of 23 October 2001 on National Emission Ceilings for Certain Atmospheric Pollutants. http://eur-lex.europa.eu

[8] UN (1997) Kyoto Protocol to the United Nations Framework Convention on Climate Change. NY, USA.

[9] EC (1996) Council Directive 96/61/EC Concerning Integrated Pollution Prevention and Control. Official Journal, L257, 26-40.

[10] EC (2010) Directive 2010/75/EU of the European Parliament and the Council of 24 November on Industrial Emissions. Official Journal of the European Union, L334, 17-119.

[11] UNECE (2014) Guidance Document on Preventing and Abating Ammonia Emissions from Agricultural, ECE/EB.AIR/120. UNECE, Geneva, 100 p.

[12] EC (2003) Integrated Pollution Prevention and Control (IPPC)-Reference Document on Best Available Techniques for Intensive Rearing of Poultry and Pigs. European Commission, $383 \mathrm{p}$.

[13] KTBL (2008) Exhaust Air Treatment Systems for Animal Housing Facilities. Volume 464 de KTBL-Schrift, Kuratorium für Technik und Bauwesen in der Landwirtschaft, ISSN 01732811.

[14] Melse, R.W. and Ogink, N.W.M. (2005) Air Scrubbing Techniques for Ammonia and Odor 
Reduction at Livestock Operations: Review of On-Farm Research in the Netherlands. Transactions of the American Society of Agricultural Engineers, 48, 2303-2313. http://dx.doi.org/10.13031/2013.20094

[15] Aarnink, A.J.A., Landman, W.J.M., Melse, R.W., Zhao, Y., Ploegaert, J.P.M. and Huynh, T.T.T. (2011) Scrubber Capabilities to Remove Airborne Microorganisms and Other Aerial Pollutants from the Exhaust Air of Animal Houses. Transactions of the ASABE, 54, 19211930. http://dx.doi.org/10.13031/2013.39833

[16] Melse, R.W., Hofschreuse, P. and Ogink, N.W.M. (2012) Removal of Particulate Matter (PM10) by Air Scrubbers at Livestock Facilities: Results of an on-Farm Monitoring Program. Transactions of the ASABE, 55, 689-698. http://dx.doi.org/10.13031/2013.41378

[17] Melse, R.W., Hofschreuse, P. and Ogink, N.W.M. (2012) Ogink, Biotrickling Filter for the Treatment of Exhaust Air from a Pig Rearing Building: Ammonia Removal Performance and Its Fluctuations. Biosystems Engineering, 113, 242-252. http://dx.doi.org/10.1016/j.biosystemseng.2012.08.010

[18] Aguilar, M., Abaigar, A., Merino, P., Estellés, F. and Calvet, S. (2010) Effect of a Bioscrubber on $\mathrm{NH}_{3}, \mathrm{~N}_{2} \mathrm{O}$ and $\mathrm{CO}_{2}$ Emissions from a Pig Facility in Spain. Proceedings of the $\mathrm{Ag}$ Eng 2010 Conference towards Environmental Technologies, Clermont-Ferrand, 6-8 September 2010, $7 \mathrm{p}$.

[19] Lagadec, S., Bellec, F., Masson, L., Dapello, C. and Landrain, P. (2015) Guingand, Survey on 31 Piggery Bioscrubbers in Brittany-Keys to Improving the Efficiency in Reducing Ammonia. Journées de la Recherche Porcine, 47, 177-182.

[20] Van der Heyden, C., Demeyer, P. and Volcke, E.I.P. (2015) Mitigating Emissions from Pig and Poultry Housing Facilities through Air Scrubbers and Biofilters: State-of-the-Art and Perspectives. Biosystems Engineering, 134, 74-93. http://dx.doi.org/10.1016/j.biosystemseng.2015.04.002

[21] Dumont, E., Lagadec, S., Landrain, P., Landrain, B. and Andrès, Y. (2014) $\mathrm{N}_{2} \mathrm{O}$ Generation Resulting from Piggery Air Biofiltration. Chemical Engineering Journal, 248, 337-341. http://dx.doi.org/10.1016/j.cej.2014.03.058

[22] Melse, R.W. and Mosquera, J. (2014) Nitrous Oxide $\left(\mathrm{N}_{2} \mathrm{O}\right)$ Emissions from Biotrickling Filters Used for Ammonia Removal at Livestock Facilities. Water Science \& Technology, 69, 994-1003. http://dx.doi.org/10.2166/wst.2013.826

[23] Guingand, N. (2009) Wet Scrubber: One Way to Reduce Ammonia and Odours Emitted by Pig Units. 60th European Association for Animal Production Meeting, Barcelona, 24-27 August 2009, 1 p.

[24] Martin, E. and Mathias, E. (2013) Analysis of the Potential of 10 Practices for Reducing Ammonia Emissions from French Livestock Farms by 2020 and 2030. ADEME, Angers, 242 p.

[25] Hassouna, M., Robin, P., Charpiot, A., Edouard, N. and Méda, B. (2013) Infrared Photoacoustic Spectroscopy in Animal Houses: Effect of Non-Compensated Interferences on aMmonia, Nitrous Oxide and Methane Air Concentrations. Biosystems Engineering, 114, 318326. http://dx.doi.org/10.1016/j.biosystemseng.2012.12.011

[26] Melse, R.W. and Mol, G. (2004) Odour and Ammonia Removal from Pig House Exhaust Air Using a Biotrickling Filter. Water Science and Technology, 50, 275-282.

[27] Aguilar, M., Abaigar, A., Merino, P., Estellés, F. and Calvet, S. (2010) Effect of Water Scrubbing on Ammonia Emissions from a Gestating Sows Building in the South of Europe. Proceedings of the 14th International Conference of the FAO ESCORENA Network on the Recycling of Agricultural, Municipal and Industrial Residues in Agriculture, Lisbon, 12-15 September 2010, 4 p.

[28] Ogawa, H., Dahl, P.J., Suzuki, T., Kai, P. and Takai, H. (2011) A Microbiological-Based Air 
Cleaning System Using a Two-Step Process for Removal of Ammonia in Discharge Air from a Pig Rearing Building. Biosystems Engineering, 109, 108-119.

http://dx.doi.org/10.1016/j.biosystemseng.2011.02.007

[29] Melse, R.W., van Wagenberg, A.V. and Mosquera, J. (2006) Size Reduction of Ammonia Scrubbers for Pig and Poultry Houses: Use of Conditional Bypass Vent at High Air Loading Rates. Biosystems Engineering, 95, 69-82.

http://dx.doi.org/10.1016/j.biosystemseng.2006.05.006

[30] Hamon, L., Lagadec, S., Dumont, E., Landrain, B., Landrain, P. and Andrès, Y. (2012) Quantification of $\mathrm{NH}_{3}$ Adsorption on Dust and Its Consequences on the Design of Biofilters for the Removal of Aerial Pollutants in Piggeries. 9th International Livestock Environment Symposium (ILES), Valencia, 8-12 July 2012, 6 p. http://dx.doi.org/10.13031/2013.41587

[31] Lemay, S.P., Girard, M., Belzile, M., Hogue, R., Duchaine, C., Létourneau, V., Martel, M., Jeanne, T., Feldes, J., Godbout, S. and Pouliot, F. (2012) Un Concept Innovateur Pour Traiter l'air émis des bâtiments porcins réduisant l'impact environnemental et favorisant la cohabitation, Rapport Final. IRDA, 125 p.

[32] Ottosen, L.D.M., Juhler, S., Guldberg, L.B., Feilberg, A., Revsbech, N.P. and Nielsen, L.P. (2011) Regulation of Ammonia Oxidation in Biotrickling Airfilters with High Ammonium Load. Chemical Engineering Journal, 167, 198-205. http://dx.doi.org/10.1016/j.cej.2010.12.022

[33] Guingand, N. (2014) Influence of the Frequency of Emptying Washwater on the Efficiency of a Bioscrubber in Reducing Ammonia, Odours and Dust Emitted by Fattening Pig Units. Journées Recherche Porcine, 46, 193-198.

[34] Sakuma, T., Jinsiriwanit, S., Hattori, T. and Deshusses, M.A. (2008) Removal of Ammonia from Contaminated Air in a Biotrickling Filter-Denitrifying Bioreactor Combination System. Water Research, 42, 4507-4513. http://dx.doi.org/10.1016/j.watres.2008.07.036

[35] Kristiansen, A., Pedersen, K.H., Nielsen, P.H., Nielsen, L.P., Nielsen, J.L. and Schramm, A. (2011) Bacterial Community Structure of a Full-Scale Biofilter Treating Pig House Exhaust Air. Systematic and Applied Microbiology, 34, 344-352. http://dx.doi.org/10.1016/j.syapm.2010.11.022

Submit or recommend next manuscript to SCIRP and we will provide best service for you:

Accepting pre-submission inquiries through Email, Facebook, LinkedIn, Twitter, etc.

A wide selection of journals (inclusive of 9 subjects, more than 200 journals)

Providing 24-hour high-quality service

User-friendly online submission system

Fair and swift peer-review system

Efficient typesetting and proofreading procedure

Display of the result of downloads and visits, as well as the number of cited articles

Maximum dissemination of your research work

Submit your manuscript at: http://papersubmission.scirp.org/

Or contact as@scirp.org 